\title{
Special Issue: Financial Market Dynamics, Monetary Policy, Investment and Trade. Papers Presented at the Fourth International Symposium in Computational Economics and Finance (Paris, April 14-16, 2016)
}

\author{
Fredj Jawadi ${ }^{1}$
}

Published online: 12 April 2018

(C) Springer Science+Business Media, LLC, part of Springer Nature 2018

\section{Introduction}

The papers in this Special Issue of Open Economies Review were presented at the Fourth International Symposium in Computational Economics and Finance (ISCEF), organized in Paris in April 2016 (www.iscef.com). The topics dealt with in the papers are separated into three main areas: (1) financial market dynamics, (2) issues related to the conduct of monetary policy, including central banks of monetary unions, and (3) issues related to investment and trade. In what follows, I briefly describe the main contributions of the papers.

The first four papers deal with the issue, financial market dynamics. Although economic theory can be shown to predict a causal relationship between leverage and asset prices, until now there have been no studies that empirically investigate that relationship. In their paper, "Broker-Dealer Leverage and the Stock Market," Apostolos Serletis and Khandokar Istiak fill this gap in the literature. Using quarterly data from 1967:1 to 2015:3, Serletis and Istiak employ linear and nonlinear causality tests to examine the dynamic relationship between broker-dealer leverage and the stock market. The authors find significant linear causality from the stock market to broker-dealer leverage and a nonlinear feedback from broker-dealer leverage to the stock market, supporting the view that the behavior of the macro economy is highly nonlinear. Additionally, their results support the hypothesis of excess-market volatility and the disconnection between prices and fundamentals since it appears that a stock market crash can occur long before a fall in fundamental asset values. In the paper, "Can We Still Lean Against the Wind? Asset Price Volatility and Optimal Policy Mix in Overlapping Generations Model," Indrani Manna uses a model that includes financial frictions in a bubble economy with Samuelson

Fredj Jawadi

fredj.jawadi@univ-evry.fr

1 University of Evry, 2 rue Facteur Cheval, 91000 Evry, France 
two-period overlapping agents to examine 'leaning-against-the-wind' macro-prudential policies. The author finds that a leaning-against-the-wind monetary policy can generate higher volatility a bubble situation than a policy of benign neglect. Additionally, the author finds that minimization of bubble volatility requires an active macro-prudential policy. In the paper, "The Size of the Rental Market and Housing Market Fluctuations," Adam Czerniak and Michal Rubaszek focus on volatility dynamics in the housing sector. The authors construct a database of variables describing the housing sector in a group of twelve (initial) euro-area members and ten other (OECD) countries over the years 19952014, and conduct a series of panel regression tests. The authors find that a welldeveloped rental market could weaken volatility in the housing sector, especially for the common-currency-area sample. However, the authors also find that differences in terms of rental market developments among monetary-union countries can be both destabilizing and a source of excess volatility. In the paper, "Oil Price Shocks and the Credit Default Swap Market," Wei Dai and Apostolos Serletis study the impact of supply and demand shocks in the global-crude-oil market on the CDX spread. Applying a structural VAR model on monthly data over the period November 2003-October 2015, the authors find that the reaction of the CDX spread to changes in the real price of crude oil differs considerably, depending on the sources of shocks; oil supply shocks, aggregate demand shocks, and oil-specific demand shocks are found to account for nearly $90 \%$ of the variation of the CDX spread in the long term. The authors argue that their analysis has direct implications for the construction of dynamic stochastic general equilibrium models relating the CDS market to the crude oil market.

The next five papers address issues related to the conduct of monetary policy. The first two papers in this section deal with inflation dynamics. In their paper, "Inflation Dynamics of Franc-Zone Countries: Determinants, Co-movements and Spatial Interactions," Eric Girardin and Cheikh A. T. Sall contrast the respective inflation performances of the two monetary unions of the African Franc Zone - representing the central and the west African regions, respectively. The authors find that persistent differences in national fiscal stances play a role in driving inflation differentials in the regions. They also find that global factors play a role in driving inflation dynamics; for spatial interactions, the authors obtain mixed results. In the paper, "How Should Central Banks Respond to Non-Neutral Inflation Expectations?, Imran H. Shah, Ian Corrick and Abdul Saboor study the net real inflation effect on output in ten developed and emerging countries and find evidence of a significant effect, suggesting that the net inflation effect on output (NIEO) could be useful as an predictive indicator of the outcomes of policy, especially for countries that have frequent episodes of high inflation and for countries which enploy inflation-targeting policy. Thus, the authors argue that the timing of monetary policy actions could be optimized to take account of this real effect of inflation. In their paper entitled: "The Demand for Money for EMU: A Flexible Functional Form Approach," William A. Barnett and Neepa B. Gaekwad focus on the issue of aggregation for monetary assets in the European Monetary Union (EMU). To this end, the authors aggregate the monetary services for the eleven EMU countries using the Divisia monetary aggregation approach. Additionally, they investigate substitutability among monetary assets for their samples of EMU-11 countries. Barnett and Gaekwad show that transaction balances and deposits with agreed maturity are income elastic. They also find that the monetary assets are not good substitutes for each other within the EMU-11. In his paper, "Optimal Currency Area: A $20^{\text {th }}$ Century Idea for the $21^{\text {st }}$ Century?," Joshua 
Aizenman argues that the net benefits of joining a currency union change over time. He also argues that the recent euro-area sovereign debt crisis demonstrated that what may seem to be a viable and successful union may turn into a bad union with strong centrifugal forces at times of asymmetric shocks, thus testing the viability of the union. Aizenman concludes that currency union of developing countries anchored to a leading global currency stabilizes inflation at a cost of inhibiting the use of monetary policy to deal with real and financial shocks. Currency unions with low financial depth and low financial integration of its members may be more stable at a cost of inhibiting the growth of sectors depending on bank funding. In his contribution, "Monetary Policy, Market Structure and the Income Shares in the U.S.," George C. Bitros focuses on the impact of monetary policy and market structure on the labor market in the United States in recent decades. The author finds significant - but opposing - effects of monetary policy on the labor market that vary with the channel under consideration. Bitros concludes that monetary policy has made a significant contribution to the decline of the U.S. labor share, at least since 2000. As for the market structure, Bitros finds that, even if firms had attempted to exercise monopoly power, it would be exceedingly difficult to exploit that power because the demand of consumers' goods is significantly price elastic.

The last three papers in this Special Issue focus on issues related to investment and trade. In the paper, "Regulation, Institutions and Aggregate Investment: New Evidence from OECD Countries," Balazs Egert studies the relationship between investment and structural policies for a panel of 32 OECD countries over the period 1985-2013. Egert finds a significant relationship between investment and the labor market. Additionally, it appears that employment protection legislation has a negative effect on the stock of capital. In this connection, the author shows that higher levels of product market regulations, such as state control, barriers to entrepreneurship, and barriers to trade and investment, could amplify the negative relationship between employment protection legislation and investment. In "New Evidence on Trade and FDI: How large is the Euro Effect?," Mariam Camarero, Estrella Gomez-Herrera, and Cecilio Tamarit assess the impact of the euro on trade using a gravity model for 28 countries over the period 1990 to 2013. The authors include time-varying fixed effects in this model. They find a positive effect of the EMU on trade and the existence of a complementary relationship between trade and FDI. In the paper, "Assessing the Effect of Trade Openness on Health in the MENA Region: A Panel Data Analysis," Fredj Jawadi, Sami El Gouddi, Zied Ftiti, and Abdeljaoued Kacem examine the effect of trade openness on the health outcomes of twelve countries in the MENA using a panel data investigation covering the period 1970-2015. The authors assess whether trade in these countries with developed economies and the rest of the world affects life expectancy and the infant mortality rate. The authors find that trade openness has a positive effect on health in the MENA region because it reduces the infant mortality rate and boosts life expectancy for both men and women. Additionally, the authors argue that their findings support the view that improved control over corruption and more focus on trade with developed countries would lead to greater technology and information spillover effects between health and trade, which would impact positively on the health sector.

Acknowledgments I am grateful to George Tavlas, the Editor-in-Chief of this journal, for his very helpful comments. 